\title{
Gastric Cancer Pathologic Regional Lymph Nodes TNM Finding v6
}

National Cancer Institute

\section{Source}

National Cancer Institute. Gastric Cancer Pathologic Regional Lymph Nodes TNM Finding v6. NCl Thesaurus. Code C61161.

A pathologic finding about one or more characteristics of gastric cancer, following the rules of the TNM AJCC V6 classification system as they pertain to staging of regional lymph nodes. 